\title{
OCCUPATIONAL SAFETY RISK ANALYSIS OF ORGANIZED INDUSTRIAL ENTERPRISES IN NEVSEHIR PROVINCE OF TURKEY BY FINE-KINNEY METHOD
}

\author{
M. Cüneyt Bağdatli ${ }^{*}{ }^{凶}$, Ahmet Mahmut Kiliç ${ }^{2}$ \\ ${ }^{* 1}$ Nevsehir Hacı Bektas Veli University, Engineering and Architecture Faculty, Department of \\ Biosystem Engineering, Nevşehir, Turkey \\ ${ }^{2}$ Cukurova University, Institute of Science, Department of Occupational Health and Safety, Adana, \\ Turkey
}

DOI: https://doi.org/10.29121/ijetmr.v7.i7.2020.722

Article Citation: M. Cüneyt Bağdatli, and Ahmet Mahmut Kiliç. (2020). OCCUPATIONAL SAFETY RISK ANALYSIS OF ORGANIZED INDUSTRIAL ENTERPRISES IN NEVSEHIR PROVINCE OF TURKEY BY FINE-KINNEY METHOD. International Journal of Engineering Technologies and Management Research, 7(7), 33-41. https://doi.org/10.29121/ijetmr.v7 ii 7.2020 .722

Published Date: 15 July 2020

Keywords:

Risk Analysis

Fine- Kinney Method

Occupational Safety

Organized Industry Enterprises

Nevsehir Province

Turkey

\section{ABSTRACT}

This research has been carried out within the scope of the solutions proposed for the evaluation of occupational safety risk analysis in 10 selected enterprises by random sampling in Organized Industrial Zone of Nevşehir province, Turkey and elimination of risk factors towards the results obtained. In scope of the study, Fine - Kinney method were used as risk assessment methods in each of the food, metal processing, machining and plastic firms. At the end of the study, a total of 122 risk factors have been identified in the whole enterprises. Commonly risks arising from falling from heights, fire, exposure to chemicals, electrical components and ergonomic situation insufficiency have been identified. In addition, risks such as insufficient environmental hygiene, lack of ventilation, excessive noise, inadequate training for emergency situations and insufficient use of protective equipment were determined. The identified risks were put forward by different method approaches and it was concluded that the findings were similar in all methods. The regulations and principles to be applied in order to eliminate or minimize the identified risks were discussed and the dimensions of the preventive measures were exhibited. As a result, audits of organized industrial enterprises related to occupational health and safety need to be conducted more strictly. In addition, the measures should put into practice in order to define identified risks and the issue should be monitored by the experts.

\section{INTRODUCTION}

Work-related accidents and injuries that they cause leads to serious problems in Turkey and many other countries. While the damages of work accidents occur economically and socially, work accidents can cause permanent injuries or even deaths. Permanent injuries in workers cause social and psychological problems.

As a result of these problems, it is extremely important to analyze the risk and safety conditions in organized industrial zone where collective industrial enterprises are located together and to take necessary measures in the light of the obtained results in order to prevent and detect accidents that may occur. It is necessary to anticipate possible work accidents in a facility and to determine the prevention activities.

(C) 2020 The Author(s). This is an open access article distributed under the terms of the Creative Commons Attribution License, which permits unrestricted use, distribution, and reproduction in any medium, provided the original author and source are credited. 
Risk assessment at the facilities creates a plan to prevent occupational accidents. Thanks to the risk assessment, the issues to be followed in terms of occupational safety are placed in order of importance and a risk prevention plan is created in this way. As a result of these procedures performed according to the risk assessment and the resulting results, the rate in the prevention of occupational accidents is increased. There is no risk assessment method that can be applied to all facilities and workplaces. Because every workplace has its own different dangers. Each method provides risk assessment in a unique system. While performing a risk assessment in a facility, the most important step is to decide which method will be applied in that facility, whether it is a single person or a team formed by experts.

Only in this way, an efficient and accurate assessment is made and the most accurate results are encountered in terms of both cost and labor. When deciding which risk assessment method to choose, factors such as the hazard class of the facility, the operations carried out in that facility, the products produced, the environmental conditions provided for those products, the size of the facility are taken into consideration. Due to improperly applied methods, there will be a delay in taking security measures or an accident will occur before measures can be taken. Correctly identified hazards prevent wrong safety measures from being taken in the workplace. It changes false security awareness in humans. This is only possible by choosing the right method.

Choosing the right risk assessment method will contribute to the prevention of occupational accidents and diseases, to provide a safe working environment in the facilities, to reduce health expenditures, to increase efficiency and the level of quality of the substances produced. Risk assessment is extremely important in order to anticipate possible accidents in the future and to eliminate the factors that will cause accident risks. It is important for the enterprises to be able to produce in a healthy working environment, in order to predict the accident risks that may occur in the employees or tools, equipment depending on the workflow in the enterprises and to eliminate the risk factors for this completely.

In enterprises where risk analysis has been previously made and possible risks are identified and precautions are taken, this will have a positive impact on production stages and employees, which will positively reflect the enterprise's welfare level. This research was carried out to determine the risks related to occupational safety with different model approaches in companies operating in the Organized Industrial Zone of Nevşehir province, Turkey and working in different fields of activity selected by random sampling and to reveal the dimensions of measures that can be taken in order to foresee possible accident risks in the future.

\section{MATERIALS AND METHODS}

The study area is located Nevşehir Organized Industrial Zone in Turkey's Nevsehir province. The place where the occupational safety risk analysis is made is the 10th $\mathrm{km}$ of the Nevşehir-Aksaray highway, The total area of Nevşehir organized industrial is 57.111,92 $\mathrm{m}^{2}$. Nevşehir Organized Industrial Zone has an industrial area of $527.944,98 \mathrm{~m}^{2} .94 \%$ of the total area is used as an industrial area. There are 84 parcels in total in Nevşehir Organized Industrial Zone. 83 of these areas are allocated to industrial enterprises. By its location, Nevşehir Organized Industrial Zone is located $40 \mathrm{~km}$ from the closest airport, Cappadocia Airport. Within the scope of the research, it was examined within the scope of occupational safety risk assessment in a total of 10 enterprises, located in the Nevşehir organized industrial zone, with food, iron processing, machining and plastic enterprises selected by random sampling. The location and position of the research area are shown in Figure 1. 


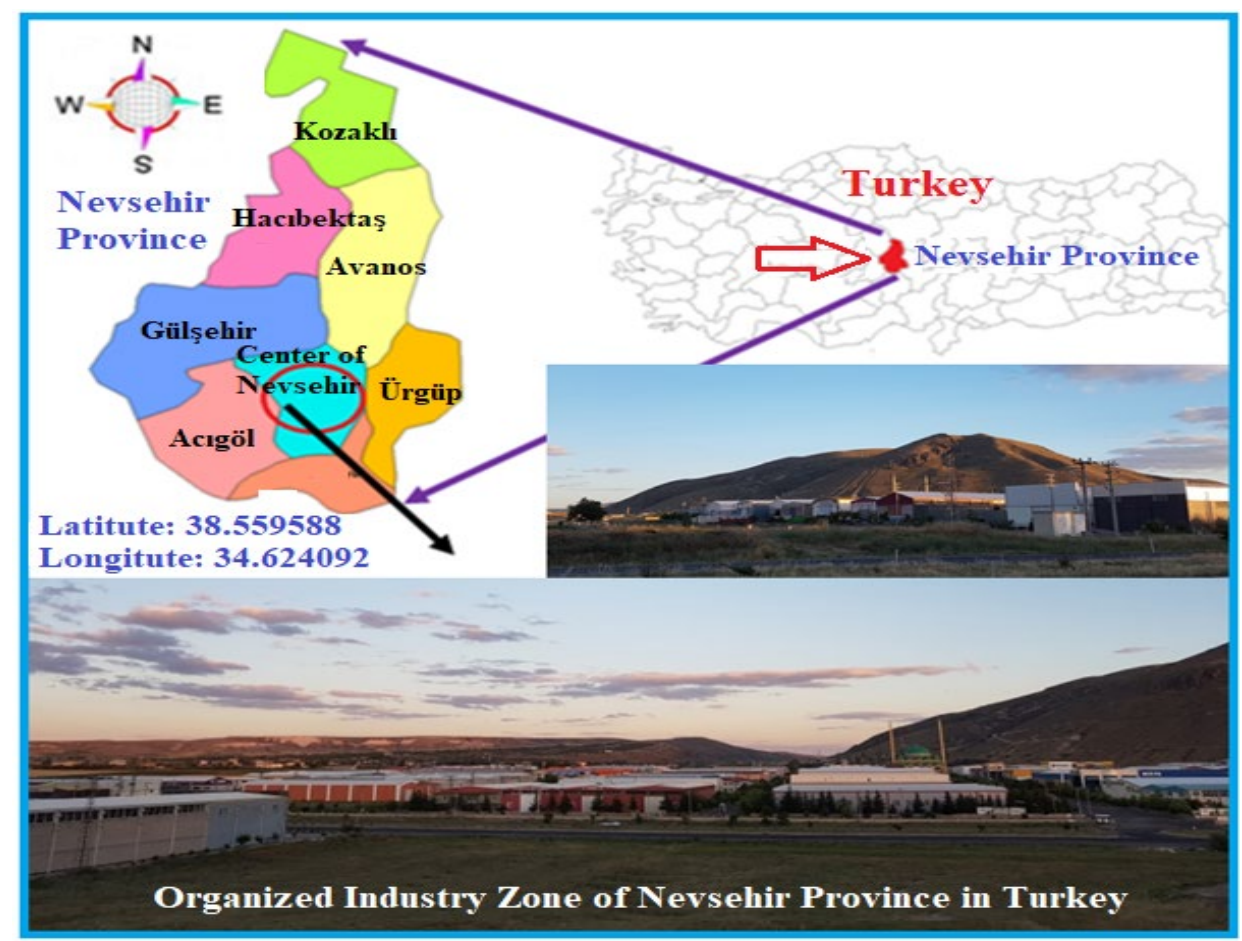

Figure 1: The Location of Research Area

Within the scope of the study, Fine - Kinney method was used for risk assessment in Nevşehir organized industrial enterprises. While calculating the risk value in this method;

\section{Risk = Probability $\mathrm{x}$ Frequency $\mathrm{x}$ Violence}

Formula was used. (Kinney and Wiruth, 1976). Information regarding the probability, frequency and severity scales used in the Fine - Kinney risk assessment method and decision making and action plans for risk level and assisting decision making are summarized in Tables 1, 2, 3 and 4.

Table 1: Probability scale (Kinney, 1976)

\begin{tabular}{|c|c|}
\hline Probability / Probability Value & Explanation \\
\hline 0,1 & The loss is theoretically impossible to occur \\
\hline 0,2 & The loss is practically impossible to occur \\
\hline 0,5 & Loss is not expected to occur but still possible \\
\hline 1 & Possible to occur but very low \\
\hline 3 & Likely to happen \\
\hline 6 & High probability of occurrence \\
\hline 10 & Loss is expected to occur \\
\hline
\end{tabular}

Table 2: Frequency scale (Kinney, 1976)

\begin{tabular}{|c|c|}
\hline Frequency scale & Probability to be seen \\
\hline 0,5 & Once a year or less \\
\hline 1 & Several times in a year \\
\hline 2 & Once or several times in a month \\
\hline 3 & Once or several times in a week \\
\hline 6 & Once or several times in a day \\
\hline 10 & Several times in an hour \\
\hline
\end{tabular}


Table 3: Violence scale (Kinney, 1976).

\begin{tabular}{|c|c|}
\hline Measure of Violence & Accident Level \\
\hline 1 & Bypass accident \\
\hline 3 & Minor damage and internal first aid \\
\hline 7 & Significant damage and external first aid \\
\hline 15 & permanent damage and loss of work \\
\hline 40 & Fatal accident \\
\hline 100 & Multiple fatal accidents \\
\hline
\end{tabular}

Table 4: Decision to risk level and action plan (Kinney, 1976).

\begin{tabular}{|c|c|}
\hline $\begin{array}{l}\text { Risk Value } \\
\quad \text { (R) }\end{array}$ & Result of Risk Assessment \\
\hline $\mathrm{R}>400$ & Unacceptable Risk, Work should be stopped and measures should be taken quickly. \\
\hline $\begin{array}{l}200<\mathrm{R}< \\
\quad 400\end{array}$ & Critical Risk, The situation of the risk is very important and should be included in the action plan. \\
\hline $\begin{array}{l}70<\mathrm{R}< \\
200\end{array}$ & $\begin{array}{l}\text { Serious Risk, The situation of the risk is important,it should be included in the action plan and the } \\
\text { work should be followed. }\end{array}$ \\
\hline $20<\mathrm{R}<70$ & $\begin{array}{l}\text { Possible Risk, It should be included in the Action Plan and the risk should be kept under } \\
\text { surveillance. }\end{array}$ \\
\hline $\mathrm{R}<20$ & Low Risk, Risk is not Priority, it may not be included in the Action Plan. \\
\hline
\end{tabular}

\section{RESEARCH FINDINGS}

In the risk assessment carried out with the Kinney method, 3 food, 3 iron processing, 2 machining and 2 plastics enterprises were evaluated and the results were analyzed according to the method developed by Finne-Kinney. There were 41 risks in iron processing and 32 risks in machining enterprises. In this sense, an example analysis is shown on a visual form developed specifically for this study and presented in Figure 2 in order to make Kinney risk assessment more visual and healthy.

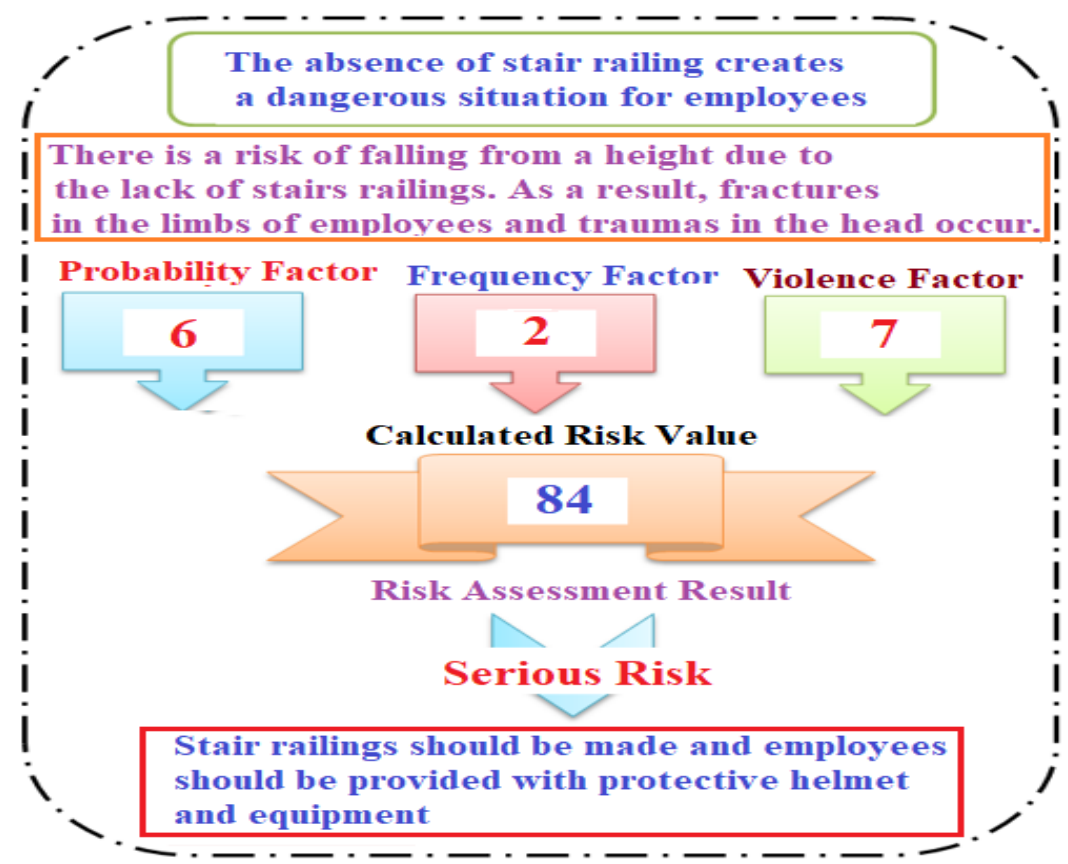

Figure 2: Schematic representation of Fine - Kinney risk assessment analysis results using a specially created form for this study in a sample food enterprise 
All factors, such as falling from height, fire, exposure to chemicals, excessive noise and sound, physical factor risks, ergonomic situations, electrical installation risks, insufficient training, biological risks and emergency risks, have been examined and results obtained in all businesses. test was presented in accordance with the evaluation criteria. As an example, the results of the risk assessment made in hair processing companies are presented in detail in Table 5.

Table 5: Results of risk assessment done by iron processing enterprise using the Fine - Kinney method

\begin{tabular}{|c|c|c|c|}
\hline $\begin{array}{l}\text { Result of Risk } \\
\text { Assessment }\end{array}$ & $\begin{array}{l}\text { I. Iron Processing } \\
\text { enterprise }\end{array}$ & $\begin{array}{c}\text { II. Iron Processing } \\
\text { enterprise }\end{array}$ & $\begin{array}{l}\text { III. Iron Processing } \\
\text { enterprise }\end{array}$ \\
\hline 1. Risk & $\begin{array}{l}\text { Lack of fire extinguisher } \\
\text { tube, Fire risk }\end{array}$ & $\begin{array}{l}\text { Lack of fire extinguisher } \\
\text { tube, Fire risk }\end{array}$ & $\begin{array}{c}\text { Ambient overheating, } \\
\text { fire risk }\end{array}$ \\
\hline $\begin{array}{c}\text { Risk } \\
\text { assessment }\end{array}$ & Serious risk & Serious risk & Serious risk \\
\hline 2. Risk & $\begin{array}{l}\text { Chemical contact, } \\
\text { poisoning risk }\end{array}$ & $\begin{array}{l}\text { Risk of Inhaling chemical } \\
\text { substance }\end{array}$ & $\begin{array}{l}\text { Explosion risk of } \\
\text { Chemical substance }\end{array}$ \\
\hline $\begin{array}{c}\text { Risk } \\
\text { assessment }\end{array}$ & Possible risk & Critical risk & Possible risk \\
\hline 3. Risk & $\begin{array}{l}\text { Noisy environment, risk of } \\
\text { hearing sense }\end{array}$ & $\begin{array}{l}\text { Risk of not concentrating } \\
\text { from high noise }\end{array}$ & $\begin{array}{l}\text { Risk of distraction from } \\
\text { excessive sound }\end{array}$ \\
\hline $\begin{array}{c}\text { Risk } \\
\text { assessment }\end{array}$ & Low risk & Possible risk & Possible risk \\
\hline 4. Risk & $\begin{array}{c}\text { Insufficient ventilation, risk } \\
\text { of physical factors }\end{array}$ & $\begin{array}{l}\text { Instrument vibration, } \\
\text { stress risk of physical } \\
\text { factors }\end{array}$ & $\begin{array}{c}\text { Risk of compressed air } \\
\text { physical factor }\end{array}$ \\
\hline $\begin{array}{c}\text { Risk } \\
\text { assessment }\end{array}$ & Serious risk & Possible risk & Serious risk \\
\hline 5. Risk & $\begin{array}{l}\text { Excessive standing, risk of } \\
\text { fatigue ergonomics }\end{array}$ & $\begin{array}{l}\text { Heavy transport, risk of } \\
\text { aching ergonomics } \\
\text { in the arm }\end{array}$ & $\begin{array}{l}\text { Ergonomic risk of heavy } \\
\text { transport in waist }\end{array}$ \\
\hline $\begin{array}{c}\text { Risk } \\
\text { assessment }\end{array}$ & Critical risk & Possible risk & Critical risk \\
\hline 6. Risk & $\begin{array}{l}\text { Passage of electrical cables } \\
\text { through the wet ground, } \\
\text { risk of electric shock }\end{array}$ & $\begin{array}{l}\text { Risk of electric shock from } \\
\text { switchboards not locked }\end{array}$ & $\begin{array}{l}\text { Insufficiency of electrical } \\
\text { hazard waming signs }\end{array}$ \\
\hline $\begin{array}{c}\text { Risk } \\
\text { assessment }\end{array}$ & Critical risk & Serious risk & Possible risk \\
\hline 7. Risk & $\begin{array}{l}\text { Insufficient training for iron } \\
\text { cutting jobs, injury risk }\end{array}$ & $\begin{array}{l}\text { Not using chemical } \\
\text { training }\end{array}$ & $\begin{array}{l}\text { Emergency training not } \\
\text { provided }\end{array}$ \\
\hline $\begin{array}{c}\text { Risk } \\
\text { assessment }\end{array}$ & Serious risk & Critical risk & Possible risk \\
\hline 8. Risk & $\begin{array}{c}\text { Metal application paints and } \\
\text { fluids contact, infection } \\
\text { biological risk }\end{array}$ & $\begin{array}{l}\text { Iron processing in } \\
\text { machine, infection risk }\end{array}$ & $\begin{array}{l}\text { Insufficient use of gloves } \\
\text { and masks, risk of } \\
\text { catching germs }\end{array}$ \\
\hline $\begin{array}{c}\text { Risk } \\
\text { assessment }\end{array}$ & Possible risk & Critical risk & Critical risk \\
\hline 9. Risk & $\begin{array}{l}\text { In case of emergency, fire } \\
\text { detector waming and warning } \\
\text { system insufficiency }\end{array}$ & $\begin{array}{l}\text { Chemical exposure, no } \\
\text { emergency hand washing } \\
\text { shower }\end{array}$ & $\begin{array}{l}\text { No emergency shower } \\
\text { washing system }\end{array}$ \\
\hline $\begin{array}{c}\text { Risk } \\
\text { assessment }\end{array}$ & Serious risk & Serious risk & Critical risk \\
\hline
\end{tabular}

Eight critical risk factors were identified in the risk assessment conducted in iron processing enterprise. II. The risk of respiratory damage due to inhalation of the chemical in the environment is high in the hair processing company. In this sense, the constant ventilation of the environment and the realization of the protective mask will reduce the risk level to minimum levels. Again II. and III. In manufacturing, there may be a risk of infection from open wounds on the hands in manufacturing. In order to prevent this, it is necessary to monitor the use of gloves and also to give training on the use of chemicals, as well as to create an emergency hand, shower system in case of chemical exposure, will show its effect as a risk reducing or completely eliminating factor. 
The lack of fire extinguishers in these enterprises, the risk of fire due to the constant heating of the air in the environment, the insufficiency of ventilation and the low air environment, the risk of electric shock due to the lack of locked electrical panels, the lack of a hand washing shower as a result of exposure to chemicals, the insufficiency of the warning system and fire detectors in case of emergency and iron In cutting operations, the risks of training insufficiency causing injuries were encountered.

In the risk assessments made in food companies, 11 risk factors, which are among the various risk factors, have entered the "serious risk" class. Another "possible risk" factor was again encountered in 11 applications and "low risk" factor was determined in 2 applications.

As a result of the evaluation made in machining companies, the critical risk factor was determined in 7 different applications. Chemical smell breathing risks have been observed in these enterprises. It has been observed that the risk of burning in the limbs of the employees as a result of chemical spills in the enterprises, insufficiency of fire tubes, ergonomic risk in the waist as a result of heavy transportation, and its condition is at a critical level. In figure 3 , there is an image regarding the controls made regarding the fire extinguisher tube.

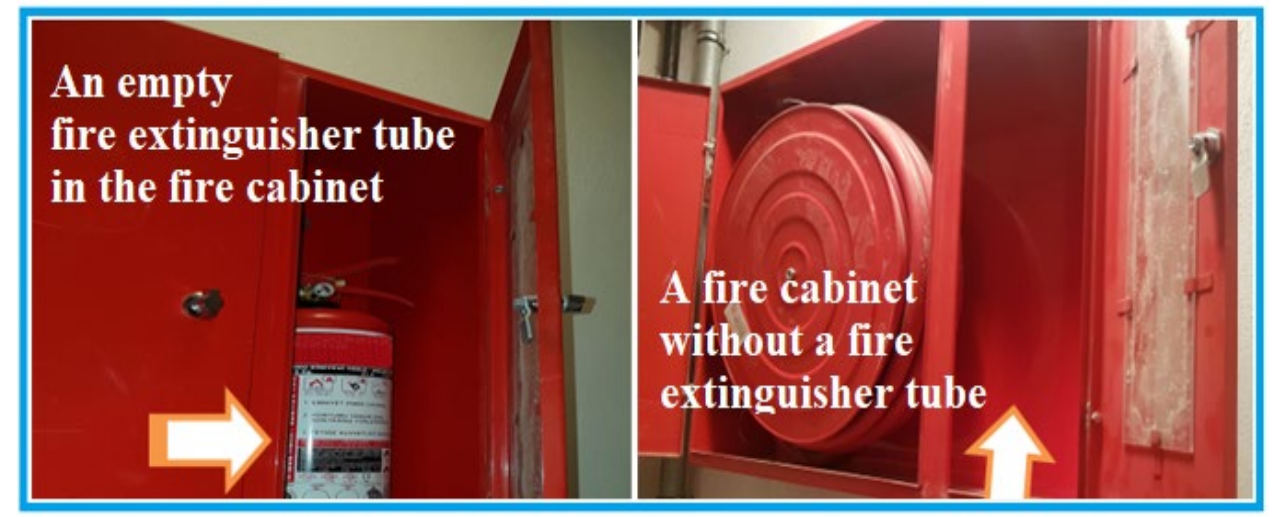

Figure 3: Fire extinguisher tube controls

In the serious risk levels encountered in plastic enterprises, there are insufficient fire extinguisher tubes in the work areas, there are sound working environments, there are risks of hearing loss due to the high noise level, dusty working environments and ventilation insufficiency, and insufficient training in the operating principles of the production lines.

In addition, serious risk factors such as the lack of training on the actions to be given by the employees in emergency situations, the ergonomic negative effects on the load carrying cause discomfort in the employees, especially the arms, neck and waist, the risk of contact with chemicals and the emergency exit door locked.

The distribution of the risk classes determined as a result of Fine - Kinney risk assessment in enterprises operating in different fields of activity evaluated within the scope of the study is presented as chart in Figure 4.

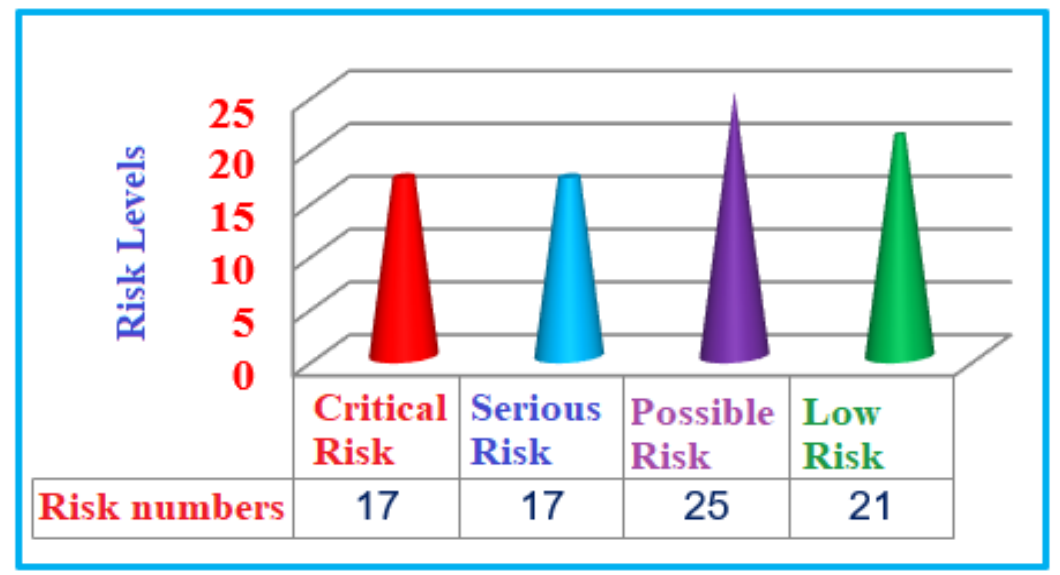

Figure 4: Distribution of the total number of risk classes encountered in organized Industry Zone 
Risk assessments were carried out in 10 enterprises, which are subject to the research and their field of activity, food, hair processing, machining and plastic using the Fine-Kinney method. In the light of the findings obtained, in summary, the common risks encountered in all of the enterprises and the solution suggestions that need to be made to eliminate these risks are summarized in Table 6.

Table 6: Common risks encountered in organized industry enterprises and solution suggestions

\begin{tabular}{|c|c|}
\hline $\begin{array}{c}\text { Risk / } \\
\text { Solution } \\
\text { Suggestions } \\
\end{array}$ & Common Risks Encountered in All Enterprises and Solution offers \\
\hline Risk & Fire Exit Risk \\
\hline $\begin{array}{c}\text { Solution } \\
\text { offers }\end{array}$ & $\begin{array}{l}\text {-The measures to be taken in accordance with the regulation on health and safety measures to be } \\
\text { taken in the workplace buildings and additions (Regulation published in Turkey Official Newspaper } \\
\text { No. } 28710 \text { dated } 12 \text { July 2013) (Anonymous 2013b). } \\
\text {-TSE ISO / TS } 11602-2 \text { fire protection - what to do in accordance with the standards for portable and } \\
\text { wheeled fire extinquishers (Anonymous 2005). }\end{array}$ \\
\hline Risk & Noise Exposure Risk \\
\hline $\begin{array}{c}\text { Solution } \\
\text { offers }\end{array}$ & $\begin{array}{l}\text { Measures to be taken in accordance with the regulation on the protection of employees from risks related } \\
\text { to noise (Regulation published in Turkey Official Newspaper No. } 28721 \text { dated } 28 \text { July 2013) } \\
\text { (Anonymous 2013d). }\end{array}$ \\
\hline Risk & Risk of Falling from Height \\
\hline $\begin{array}{c}\text { Solution } \\
\text { offers }\end{array}$ & $\begin{array}{l}\text { - Measures to be taken in accordance with the regulation on health and safety measures to be taken } \\
\text { in workplace buildings and additions (Regulation published in Turkey Official Newspaper No. } 28710 \\
\text { dated } 12 \text { Julv 2013) (Anonvmous } 2013 \mathrm{~b} \text { ) }\end{array}$ \\
\hline Risk & Risks from Ergonomic Condition Deficiency \\
\hline $\begin{array}{c}\text { Solution } \\
\text { offers }\end{array}$ & $\begin{array}{l}\text { Measures to be taken in accordance with the health and safety conditions regulations in the use of work } \\
\text { equipment (Regulation published in Turkey Official Newspaper No. } 28628 \text { dated } 25 \text { April 2013) } \\
\text { (Anonymous } 2013 \mathrm{c} \text { ). }\end{array}$ \\
\hline Risk & Electric Shock Risks \\
\hline $\begin{array}{c}\text { Solution } \\
\text { offers }\end{array}$ & $\begin{array}{l}\text {-The measures to be taken in accordance with the regulation on health and safety measures to be taken } \\
\text { in the workplace buildings and additions (Regulation published in Turkey Official Newspaper } \\
\text { No. } 28710 \text { dated } 12 \text { July } 2013 \text { ) (Anonymous } 2013 \mathrm{~b} \text { ). } \\
\text { - Measures to be taken in the use of work equipment in accordance with the health and safety conditions } \\
\text { regulation (Regulation published in Turkey Official Newspaper No. } 28628 \text { dated } 25 \text { April 2013) } \\
\text { (Anonymous 2013c). }\end{array}$ \\
\hline Risk & Insufficient Ventilation Risks (Insufficient physical environment) \\
\hline $\begin{array}{c}\text { Solution } \\
\text { offers }\end{array}$ & $\begin{array}{l}\text { Measures to be taken in accordance with the regulation on health and safety measures to be taken in } \\
\text { workplace buildings and additions (Regulation published in Turkey Official Newspaper No. } 28710 \text { dated } \\
12 \text { Julv 2013) (Anonvmous 2013c). }\end{array}$ \\
\hline Risk & Risks from Unhygienic Environment \\
\hline $\begin{array}{c}\text { Solution } \\
\text { offers }\end{array}$ & $\begin{array}{l}\text { Measures to be taken in accordance with the hygiene (workplace) education regulation } \\
\text { (Reaulation published in Turkev Official Newspaper No. } 28698 \text { dated Julv 5. 2013) (Anonvmous } 2013 \text { f). }\end{array}$ \\
\hline Risk & Risks from Caused by Chemical Substances \\
\hline $\begin{array}{c}\text { Solution } \\
\text { offers }\end{array}$ & $\begin{array}{l}\text { Measures to be taken in accordance with the regulation on health and safety precautions in chemical } \\
\text { work (Regulation published in Turkey Official Newspaper No. } 28733 \text { dated } 12 \text { August 2013) } \\
\text { (Anonymous 2013a). }\end{array}$ \\
\hline Risk & Risks from Tools and Equipment \\
\hline $\begin{array}{c}\text { Solution } \\
\text { offers }\end{array}$ & $\begin{array}{l}\text { Measures to be taken in accordance with the health and safety conditions regulations in the use of work } \\
\text { equipment (Regulation published in Turkey Official Newspaper No. } 28628 \text { dated } 25 \text { April 2013) } \\
\text { (Anonymous 2013c). }\end{array}$ \\
\hline Risk & Risks of Training Insufficiency for Emergency Situations \\
\hline $\begin{array}{c}\text { Solution } \\
\text { offers }\end{array}$ & $\begin{array}{l}\text { Measures to be taken in accordance with the regulation on the procedures and principles of the } \\
\text { occupational health and safety training of employees (Regulation published in Turkey Official } \\
\text { Newspaper No. } 28648 \text { dated } 15 \text { May 2013) (Anonymous 2013e). }\end{array}$ \\
\hline
\end{tabular}




\section{CONCLUSIONS AND RECOMMENDATIONS}

A total of 122 risk factors were identified in the repair of the enterprises subject to the research. In the enterprises, the risks arising from falling from height, fire, chemical exposure, electrical components and the lack of ergonomic status have been identified. It is obvious that these situations, in which hazardous risk factors are high in all of the companies subject to research, will increase the risk of loss of material and moral damages on the employees, the production loss in the workplace. As a result, audits of organized industrial enterprises regarding occupational health and safety should be done more strictly. In addition, measures to be taken to prevent identified risks should be put into practice, should not be left on paper and it is recommended that the subject be closely followed by the relevant experts.

\section{SOURCES OF FUNDING}

None.

\section{CONFLICT OF INTEREST}

None.

\section{ACKNOWLEDGMENT}

This research was carried out in 2019 by using the results of the master's thesis titled "Occupational safety risk analysis and model approach strategies in Nevşehir organized industrial enterprises" conducted at the Department of Occupational Health and Safety at Çukurova University, Institute of Science. (Thesis Number: 554869) Council of Higher Education in Turkey).

\section{REFERENCES}

[1] Anonymous 2013a, Kimyasal maddelerle çalışmalarda sağlık ve güvenlik önlemleri hakkında yönetmelik, (Regulation on health and safety measures in working with chemical substances) https://www.resmigazete.gov.tr/eskiler/2013/08/20130812-1.htm Access date (25.06.2019) (in Turkish)

[2] Anonymous 2013b, İşyeri bina ve eklentilerinde alınacak sağlık ve güvenlik önlemlerine ilişkin yönetmelik, (Regulation on health and safety measures to be taken in workplace buildings and add-ons) https://www.resmigazete.gov.tr/eskiler/2013/07/20130717-2.htm Access date (25.06.2019) (in Turkish)

[3] Anonymous 2013c, İş ekipmanlarının kullanımında sağlık ve güvenlik şartları yönetmeliği (Regulation on health and safety conditions in the use of work equipment) https://www.mevzuat.gov.tr/mevzuat?MevzuatNo=18318\&MevzuatTur=7\&MevzuatTertip=5 Access date (29.06.2019) (in Turkish)

[4] Anonymous 2013d, Çalışanların gürültü ile ilgili risklerden korunmalarına dair yönetmelik, (Regulation on the protection of employees from risks related to noise) https://www.resmigazete.gov.tr/eskiler/2013/07/20130728-11.htm Access date (26.06.2019) (in Turkish)

[5] Anonymous 2013e, Çalışanların iş sağlığı ve güvenliği eğitimlerinin usul ve esasları hakkında yönetmelik (Regulation on the procedures and principles of the occupational health and safety training of employees) https://www.mevzuat.gov.tr/mevzuat?MevzuatNo=18371\&MevzuatTur=7\&MevzuatTertip=5 Access date (20.06.2019) (in Turkish)

[6] Anonymous 2013f, Hijyen eğitimi yönetmeliği, (Hygiene education regulations) https://www.resmigazete.gov.tr/eskiler/2013/07/20130705-3.htm Access date (20.05.2019) (in Turkish) 
[7] Bağdatlı, M. C., Kılıç, A. M., 2019. Occupational safety risk analysis and model approach strategies in Nevşehir organized industrial enterprises, Çukurova University, Institute of Science, MSc Thesis, Adana, Turkey, Thesis Number: 554869) Council of Higher Education in Turkey)

[8] Kinney, G. F., Wiruth, A. D. 1976. Practical Risk Analysis for Safety Management (No. NWC-TP-5865). Naval Weapons Center China Lake CA. 